\title{
Methemoglobinemia in a Newborn
}

\section{Shristi Shakya, Nisha Jyoti Shrestha and Kalpana Upadhaya Subedi}

Department of Neonatology, Paropakar Maternity and Women's Hospital, Thapathali, Kathmandu, Nepal.

ABSTRACT
Methaemoglobinaemia in a newborn is a rare cause of cyanosis. We report a case of a new born presented with
cyanosis and with normal cardio-pulmonary system. He was diagnosed as methaemoglobinaemia due to
persistent cyanosis despite administration of oxygen and arterial blood gas collection appeared chocolate
brown in colour. As methaemoglobin report was in mild range (11.7\%), he was treated symptomatically.
Key words: cyanosis; newborn; methemoglobinemia

Correspondence: Shristi Shakya. Department of Neonatology, Paropakar Maternity and Women's Hospital, Thapathali, Kathmandu, Nepal. Email:shristi_shakya@hotmail.com

DOI: http://dx.doi.org/10.3126/mjsbh.v19i1.26567

Submitted on: 2019-10-19

Accepted on: 2019-12-07 


\section{INTRODUCTION}

A newborn presenting with sign of cyanosis in the first day of life is challenging to diagnosis. Cyanosis can be a sign of severe cardiac, respiratory, central nervous system or other disorders. Cyanosis can also be caused by a reduced blood oxygen carrying capacity secondary to an abnormal form of haemoglobin, such as methaemoglobinaemia. ${ }^{1,2}$

\section{CASE REPORT}

A newborn baby presented at NICU with sign of cyanosis soon after birth. He was born at full term spontaneous vaginal delivery at 40 week of gestation, weighing $2900 \mathrm{gm}$ to a 32 year old second gravida mother with full antenatal care and no perinatal problems. APGAR score was 7 and 8 at one and five minutes respectively. Baby had cyanosis and not maintaining $\mathrm{SpO}_{2}$ despite administration of oxygen so was suspected of having congenital heart disease. Septic work up, $\mathrm{ABG}$ and chest X-ray was done and was found to be normal and first line antibiotics, injection amikacin and injection ampicillin was started. Echocardiography (ECHO) was done on second day of life to rule out cyanotic congenital heart disease and suggestive of Atrial septal defect (ASD) secundum $3.4 \mathrm{~mm}$ and tiny closing type of insignificant Patent ductus arteriosus (PDA), both left to right shunt, trace tricuspid regurgitation (TR) with normal pulmonary atresia (PA) pressure, mildly dilated right atrium (RA) and right ventricle (RV). Baby was not improving clinically and had persistent cyanosis. Re-septic workup was done and broad spectrum antibiotics were upgraded. On the seventh day of life ECHO was repeated to evaluate but finding were same as pervious. On the ninth day of life arterial blood for arterial blood gas collection appeared to be chocolate brown colour which was suggestive methaemoglobinaemia. So, spectrophotometry for methaemoglobin was collected which was $11.7 \%$ (normal $<1.5 \%$ ). As the methaemoglobin level was in mild range, we did not provide methylene blue so, treated symptomatically. On follow up he was thriving well with no clinical cyanosis and $\mathrm{SaO}_{2}$ in normal range.

\section{DISCUSSION}

Cyanosis becomes visible when there is $>3-5 \mathrm{~g} / \mathrm{dL}$ of deoxygenated haemoglobin $/ \mathrm{dL}^{1}$. Methaemoglobinaemia should be suspected in newborns, in the absence of any obvious cardiac and pulmonary dysfunction that are persistent cyanosis and hypoxia and did not improve in the administration of oxygen supplementation. ${ }^{1-3}$

In methaemoglobinaemia, the haeme iron is oxidised to the ferric $\left(\mathrm{Fe}^{3+}\right)$ rather than ferrous $\left(\mathrm{Fe}^{2+}\right) .^{1-5}$ The ferric haeme in methaemoglobin is unable to neither bind nor transport oxygen. These reduce the affinity of haemoglobin to oxygen and shift the curve to the left leading to tissue hypoxia and acidosis. ${ }^{1-3,5}$ Methaemoglobinaemia is a rare disease that occur when the red blood cells contain methaemoglobin at levels higher than $1 \%{ }^{1,6}$

Methaemoglobinaemia has two forms; inherited and acquired. ${ }^{2}$ Inherited disorder causing methaemoglobinaemia resulted from an enzymatic deficiency of Nicotinamide adenine dinucleotide cytochrome b5 reductase, ${ }^{1,2,5}$ which is classified into two distinct phenotypes. In type $\mathrm{I}$, the most common form, the deficiency of $\mathrm{NADH}$ cytochrome b5 activity is found only in erythrocytes, with other cell types unaffected., 3 In type II, the enzyme deficiency and occur when the enzyme doesn't work anywhere in the body. ${ }^{5}$

Acquired methaemoglobinaemia is more common than the inherited forms. It occurs in some people after they are exposed to certain chemicals and drugs include anaesthetics such as benzocaine, benzene. Certain antibiotics including dapsone and chloroquine and nitrites. ${ }^{4,5}$

Clinically the symptoms vary upon the degree percentage of methaemoglobin. If the methaemoglobin rise above $15 \%$ cyanosis occurs. And methaemoglobin more than 30\% respiratory, cardiac and neurological symptoms arise, level higher than $79 \%$ are usually fatal. ${ }^{2,5}$ 
In patients with methaemoglobinaemia arterial blood is chocolate brown in colour ${ }^{1,5}$ and arterial blood gas analysis reveals a high partial pressure of $\mathrm{O}_{2}$ with a normal $\mathrm{SaO}_{2}$, well above saturation given by pulse oxymetry. ${ }^{2}$ A simple bedside test is to place one or two drops of the patient's blood on white filter paper. If the infant has methaemoglobinaemia the blood will not turn red when exposed to air, it will have a chocolate hue., ${ }^{4,6}$

Methylene blue is the only treatment in infant who has markedly increased methaemoglobin level. ${ }^{1,2}$ Administration intravenously $1 \mathrm{mg} / \mathrm{kg}$ of $1 \%$ solution of methylene blue in normal saline is the treatment of choice. ${ }^{4}$

\section{CONCLUSIONS}

Methaemoglobinaemia is a rare occurrence in the neonatal period; its incidence is largely unknown. The diagnosis should be considered in case of severe cyanosis non-response to oxygen administration, after ruling out cardio pulmonary dysfunction. So, early recognition is necessary to prevent unnecessary investigations and delay management.

To cite this article: Shakya S, Shrestha NJ, Subedi KU.Methemoglobinemia in a newborn. MJSBH. 2019;18(2); 45-7.

Conflict of Interest: None declared

\section{REFERENCES}

1. Da-Silva SS, Sajan IS, Underwood JP. Congenital methemoglobinemia: a rare cause of cyanosis in the newborn- a case report. Pediatrics. 2003 Aug;112(2):158-61.

DOI: https://doi.org/10.1542/peds.112.2.e158

2. Carreira R, Palaré MJ, Prior AR, Garcia P, Abrantes M. An unusual cause of neonatal cyanosis. BMJ Case Rep. 2015;9:1-4.

DOI: https://doi.org/10.1136/bcr-2014-208371

3. DomBourian M, Ezhuthachan A, Kohn A, Berman B, Sykes E. A 5-hour-old male neonate with cyanosis. Lab med. 2015;46(1):60-3.

DOI: https://doi.org/10.1309/LMBQIZ5DRS4K9IMD

4. Wright RO, Lewander WJ, Woolf AD. Methemoglobinemia; Etiology, Pharmocology, and Clinical Management. Ann Emerg Med.1999;34:646-56.

DOI: https://doi.org/10.1016/S0196-0644(99)70167-8

5. Singh A, Kler N, Thakur A. Bluish discoloration in an infant. NeoReviews. 2017;18:438. DOI: https://doi.org/10.1542/neo.18-7-e438

6. Khade H, Raju U, Deshmukh T, Srivastav G and Kadiri V. Neonatal congenital methemoglobinemia- a case report. Indian J Med Case Rep. ISSN: Online International Journal. 2016;5(4):12-7. 